\title{
PONTIANAK COFFEE SHOP
}

\author{
Novan$^{1}$, Emilya Kalsum², Lestari $^{3}$ \\ ${ }^{1}$ Mahasiswa, Program Studi Arsitektur, Fakultas Teknik, Universitas Tanjungpura. \\ Cristiannovan.cn@gmail.com \\ ${ }^{2}$ Program Studi Arsitektur, Fakultas Teknik, Universitas Tanjungpura \\ ${ }^{3}$ Program Studi Arsitektur, Fakultas Teknik, Universitas Tanjungpura
}

Naskah diajukan pada: 18 Februari 2021

Naskah revisi akhir diterima pada: 21 Februari 2021

\begin{abstract}
Abstrak
Pontianak sebagai pusat aktivitas di Kalimantan Barat sudah banyak memiliki coffee shop yang tersebar di berbagai penjuru kota, ini menunjukan bahwa minat masyarakat terhadap kopi meningkat. Namun, coffee shop di Pontianak masih sangat minim yang memiliki tempat pengolahan, penjualan alat dan produk kopi, serta belum adanya wadah edukasi guna memberikan informasi mengenai kopi. Oleh karena itu, diperlukan sebuah perancangan coffee shop dengan menyediakan fasilitas penunjang yang dapat mewadahi kebutuhan-kebutuhan tersebut. Metodologi perancangan Pontianak Coffee Shop ini meliputi tahap observasi, pengumpulan data, mengidentifikasi, analisis data, konsep perencanaan dan perancangan. Perancangan bangunan Pontianak Coffee Shop ini dibuat dengan tiga fungsi yaitu fungsi komersil, fungsi produksi, dan fungsi edukasi yang memiliki fasilitas penunjang seperti pengolahan, workshop, dan penjualan. Konsep bangunan mengadopsi bentuk bangunan tropis, dan memberikan sentuhan alam pada interior dan eksterior bangunan. Konsep yang diterapkan pada struktur ialah penggunaan kolom persegi, sedangkan konsep arsitektur lingkungan dan utilitas berupa penyeimbangan penggunaan energi alami dan buatan, dan menggunakan penghawaan alami yang maksimal. Hasil perancangan berupa bangunan coffee shop yang tidak hanya menyajikan kopi namun juga menjadi ikon bagi Kawasan khususnya dan Pontianak umumnya.
\end{abstract}

Kata-kata Kunci: Coffee Shop, Perancangan, Pontianak

\begin{abstract}
Pontianak as the economic center in West Kalimantan has many coffee shops spread around the city, this shows that people's interest in coffee is increasing. however, there are still very few coffee shops in Pontianak that have processing facilities, selling coffee tools and products, and there is no educational platform to provide information about coffee. Therefore, design for a coffee shop that provides facilities that can accommodate these needs. Research method for Pontianak Coffee Shop includes the stages of observation, data collecting, identification, data analysis, planning, and design concept. The design of the Pontianak Coffee Shop building is made with 3 functions, namely a commercial function, a production function, and an educational function which has supporting facilities such as processing, workshops, and sales. The building concept adopts a tropical building form, and touch of nature to the interior and exterior of the building. The concepts are applied in structural is the use of square columns, while the environmental and utility architectural concepts are in the form of balancing the use of natural and artificial energy, and using maximum of natural ventilation systems. Design results are coffee shops building that provides not only coffee but also becomes an icon for the region in particular and Pontianak in general.
\end{abstract}

Keywords: Coffee Shop, Design, Pontianak

\section{Pendahuluan}

Kopi adalah minuman yang terbuat dari biji kopi yang telah diolah menjadi bubuk kopi. Kopi pertama kali muncul di Ethiopia, Afrika dan masuk ke Indonesia pada tahun 1696 dengan nama kopi Arabika. Secara garis besar terdapat dua jenis pohon kopi yaitu Kopi Arabika dan Kopi Robusta. Dua 
jenis kopi ini juga ditemukan di wilayah Indonesia, namun kopi ini memiliki rasa dan aroma yang beragam tergantung pada daerah produksinya. (Distan, 2019)

Pontianak merupakan salah satu kota yang memiliki ketertarikan yang kuat terhadap kopi. Hal ini ditunjang dengan kebudayaan nongkrong di Pontianak yang masih kental. Selain dikenal sebagai Kota Khatulistiwa, Pontianak juga dikenal sebagai Kota 1000 Warung Kopi. Tidak sulit untuk menemukan warung kopi atau cafe yang menyediakan kopi sebagai komoditas utamanya. Jalan Gusti Hamzah terdapat 18 warung kopi, Jalan Putri Candramidi terdapat 11 Warung Kopi, Jalan Reformasi terdapat 30 warung kopi, Jalan Imam Bonjol terdapat warung kopi, Jalan Gajah Mada, Tanjungpura dan sekitarnya terdapat 115 warung kopi. Jalan Gajah Mada dicanangkan sebagai coffee street di Kota Pontianak pada tahun 2011 (Barus, 2011). Namun masih banyak masyarakat sekitar yang masih kurang memahami kopi khususnya kopi Indonesia, karena belum adanya wadah atau fasilitas untuk memberikan informasi dan edukasi tentang seluk beluk kopi.

Coffee shop cenderung terlihat sebagai tempat yang bergengsi karena interior dan eksteriornya yang menarik, sehingga menjadi pilihan utama bagi yang ingin menikmati kopi dengan fasilitas yang baik dan tempat yang tepat jika ingin menikmati kopi dengan tenang. Di sisi lain, coffee shop harus memiliki barista yang berperan penting dalam menyajikan kopi. Barista secara tidak langsung berada di garis depan dalam menyajikan atau menyeduh kopi di coffee shop. Barista merupakan profesi meracik kopi dengan menggunakan berbagai teknik dan alat, tidak hanya sekedar menyeduh kopi dengan menuangkan air panas untuk menghasilkan minuman kopi.

Perancangan coffee shop bertujuan untuk membuat wadah atau fasilitas yang menyediakan segala informasi tentang kopi, pembelajaran ilmu kopi untuk menjadi barista, menyediakan tempat untuk penjualan alat dan produk yang berhubungan dengan kopi, dan juga sebagai tempat bertemunya para penikmat kopi.

\section{Kajian Pustaka}

Coffee shop menurut Metelka (1991) dalam Sugiarto dan Sulartiningrum (1996) adalah suatu usaha yang bergerak dibidang makanan yang dikelola secara komersial yang menyediakan minuman atau makanan ringan bagi para tamu dalam suasana informal tanpa mengikuti aturan standar layanan. Coffee shop merupakan industri retail yang saat ini berkembang pesat, coffee shop tidak hanya sebatas menawarkan produk saja, namun jasa pelayanan merupakan salah satu poin lebih oleh setiap coffee shop apabila memberikan pelayanan dengan baik kepada setiap konsumen (Yazid, 1999).

Budaya minum kopi di Kota Pontianak bisa dikatakan sebagai serapan dari budaya tionghoa yang menghabiskan waktunya di warung kopi untuk sarapan dan berinteraksi dengan sesama teman sebelum berangkat kerja. Hal tersebutlah yang menyebabkan meja di warung kopi berukuran kecil. Budaya minum kopi di Pontianak juga memiliki banyak istilah seperti kopi pancong atau kopi setengah. Saat ini kedai kopi merupakan salah satu tempat usaha waralaba di Kota Pontianak yang digemari oleh anak muda dan pelajar. Ibarat sebuah magnet yang membuat anak muda dan pelajar berlomba mengisi waktu luang hanya untuk menghabiskan secangkir kopi dan bersantai lama di warung kopi yang menyediakan fasilitas seperti jaringan internet (Prayudi, 2015).

Susunan organisasi pada coffee shop bergantung pada ukuran coffee shop, jumlah pengunjung, dan pelayanannya. Adapun pelaku dalam mengelola sebuah coffee shop seperti coffee shop manager, supervisor coffee shop, coffee shop captain, head barista, barista, waiter, busboy/girl. (Boston, 2020)

Kualitas ruang pada coffee shop tidak hanya bergantung pada estetika, tetapi juga pada kenyamanan termal, visual, dan akustik. Selain itu coffee shop merupakan bangunan publik yang didatangi oleh banyak orang. Kebisingan dari dalam maupun luar ruangan membutuhkan perencanaan akustika yang baik. Pencahayaan dapat menciptakan suasana ruangan, hingga penghawaan yang baik untuk pengunjung yang datang. Oleh karena itu, perlu memperhatikan beberapa aspek dalam penataan ruang untuk mendapatkan ruang yang berkualitas. 


\section{Metode}

Pada perancangan coffee shop ini menggunakan metode yang membandingkan hasil observasi dengan studi literatur, studi banding dan standar yang berlaku untuk coffee shop serta fasilitasnya, dan menganalisis aspek-aspek internal dan eksternal. Analisa internal adalah analisis penulis terhadap fungsi dan sistem yang akan digunakan pada perancangan seperti pengelompokan kegiatan, analisa pelaku, kebutuhan ruang, persyaratan ruang, hubungan ruang, dan organisasi ruang. Sedangkan analisa eksternal mengacu pada kondisi lingkungan di lokasi perancangan seperti analisa perletakan, analisa sirkulasi, analisa orientasi, analisa vegetasi, analisa zonasi, sistem struktur, dan sistem utilitas.

Pengumpulan data dilakukan melalui observasi langsung di lapangan, setelah mengumpulkan semua data dilakukan analisis terkait dengan perancangan. Data yang dianalisis mulai dari kebutuhan ruang dan fungsi pada bangunan, kemudian menganalisis struktur dan utilitas bangunan, menganalisis tapak dan arsitektur lingkungan untuk mendapatkan konsep perletakan, sirkulasi, orientasi, vegetasi dan zonasi bangunan.

Tahap konsep yaitu konsep perancangan berdasarkan analisis yang telah dilakukan. Kemudian tahap prarancangan merupakan tahap pemindahan hasil kedalam gambar kerja. Tahap pengembangan rancangan yaiu tahap lanjutan dari tahap prarancangan, produk berupa gambar detail, presentasi, laporan, dan maket.

\section{Hasil dan Pembahasan Lokasi Perancangan}

Lokasi perancangan berada di Jl. Reformasi, Kelurahan Bansir darat, Kecamatan Pontianak Tenggara. Luas lahan tersebut adalah 0,38 hektar dengan kondisi masih berupa lahan kosong yang pada saat ini masih rawa-rawa. Berdasarkan Peraturan Daerah Kota Pontianak tentang Rencana Tata Ruang Wilayah Kota Pontianak Tahun 2013 -2033 menetapkan bahwa ketentuan umum pada Jl. Reformasi merupakan pola ruang untuk Pendidikan. Fungsi sekitar pada lokasi perancangan merupakan daerah perumahan, perdagangan dan jasa. Potensi pada lokasi perancangan yaitu dekat dengan kampus, sehingga dapat menarik mahasiswa untuk datang berkunjung. Lokasi perancangan dapat diakses oleh pejalan kaki, kendaraan beroda dua dan empat. Kondisi eksisting tapak dapat dilihat pada gambar 1.

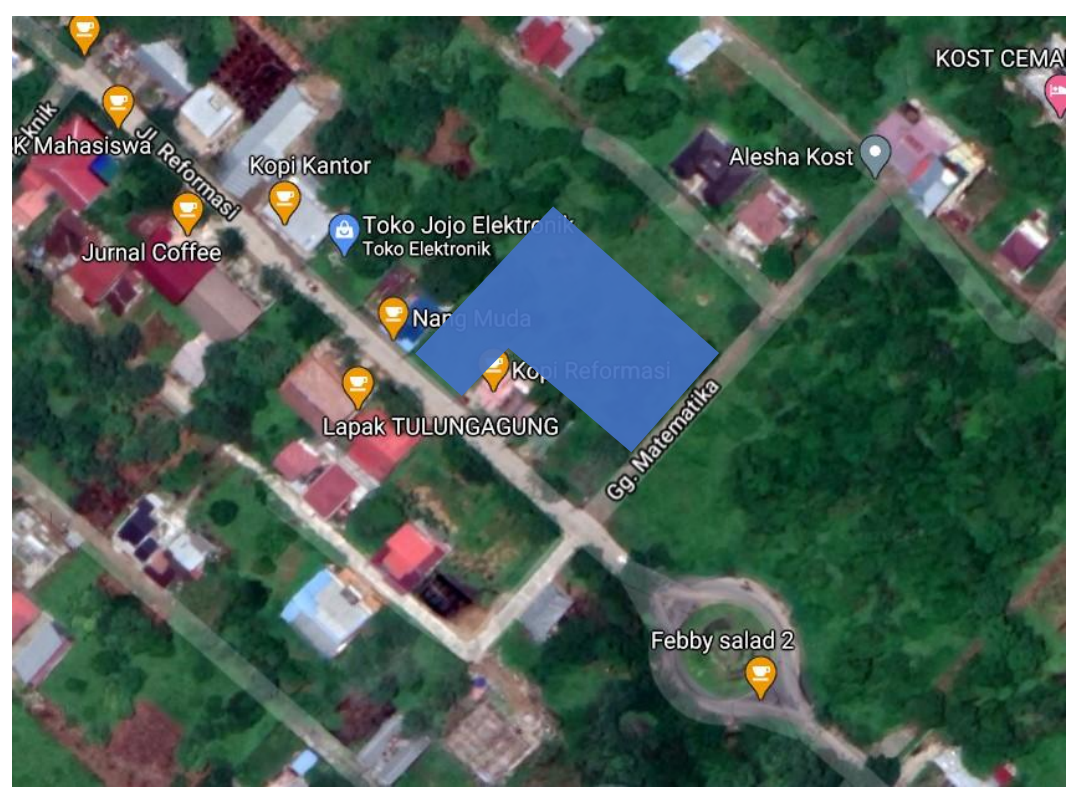

Gambar 1. Kondisi Eksisting Tapak

Sumber: Penulis, 2020 


\section{Landasan Konseptual}

Analisis perletakan ditentukan berdasarkan peraturan daerah mengenai lokasi, panca indra, iklim dan budaya. Terdapat area garis sempadan yang tidak boleh dibangun berukuran 10 meter. Analisis terhadap panca indera yaitu, area belakang bangunan memiliki kebisingan yang baik sehingga dapat digunakan untuk fungsi pendukung. Area depan merupakan area yang cocok dijadikan fungsi utama. Analisis terhadap iklim, perletakan bangunan diletakan di tengah agar sirkulasi angin dapat mengalir dengan baik, lebih jelas dapat dilihat pada gambar 2.

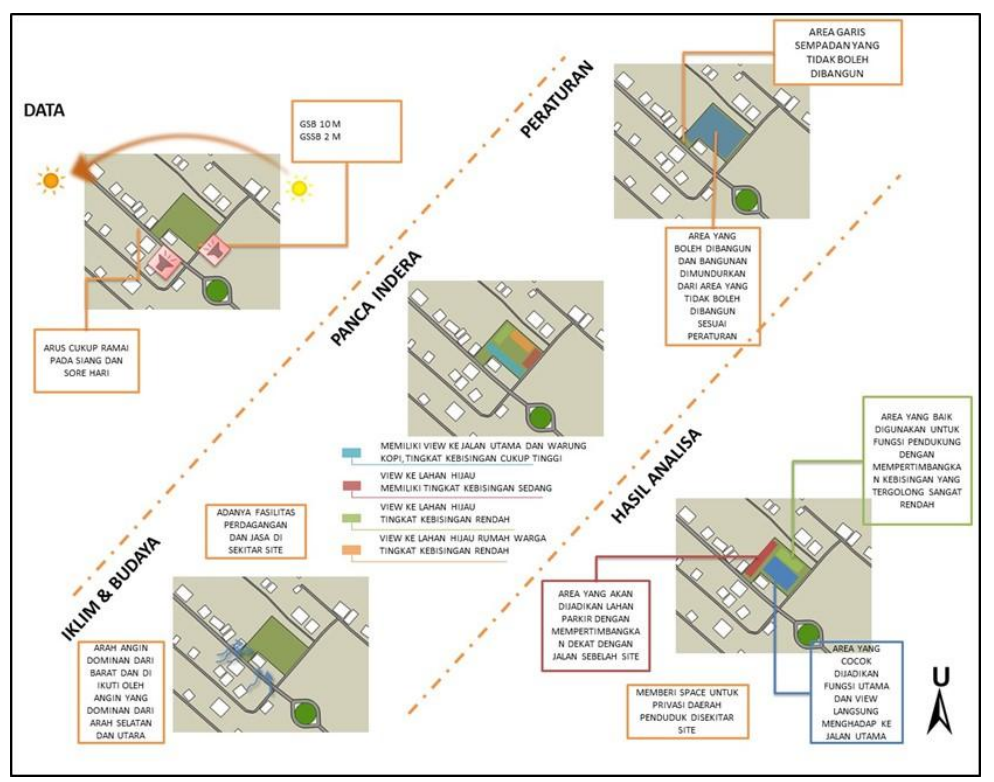

Gambar 2. Analisis Perletakan Pontianak Coffee Shop

Sumber: Penulis, 2020

Analisis sirkulasi pada lokasi perancangan yang berada di Jl. Reformasi sebagai akses utama menuju site. Analisis terhadap sirkulasi terdapat satu jalan pada sisi samping site. Jalur masuk dan keluar dapat di akses melalu Jl. Reformasi, lebih jelas dapat dilihat pada gambar 3.

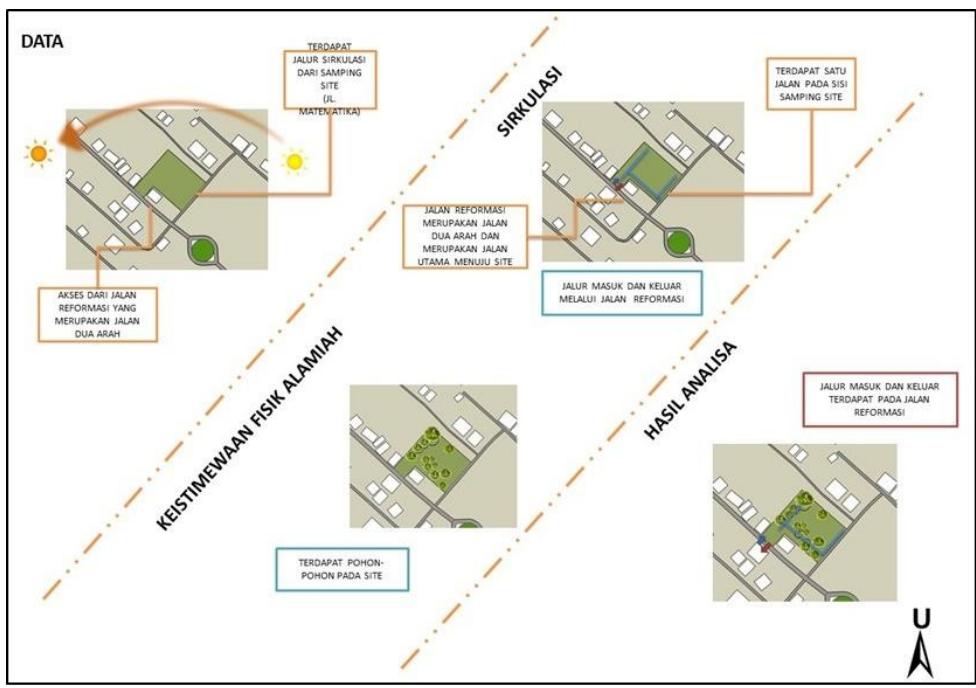

Gambar 3. Analisis Sirkulasi Pontianak Coffee Shop

Sumber: Penulis, 2020

Analisis orientasi merupakan analisis untuk menentukan arah orientasi bangunan. Mempertimbangkan orientasi bangunan agar tapak bisa memperoleh sinar matahari pagi lebih banyak, 
serta angin yang diperoleh tidak langsung. Orientasi diarahkan ke jalur utama, akan tetapi sedikit di miringkan agar tidak terhalang oleh bangunan pada depan site, dapat dilihat pada gambar 4.

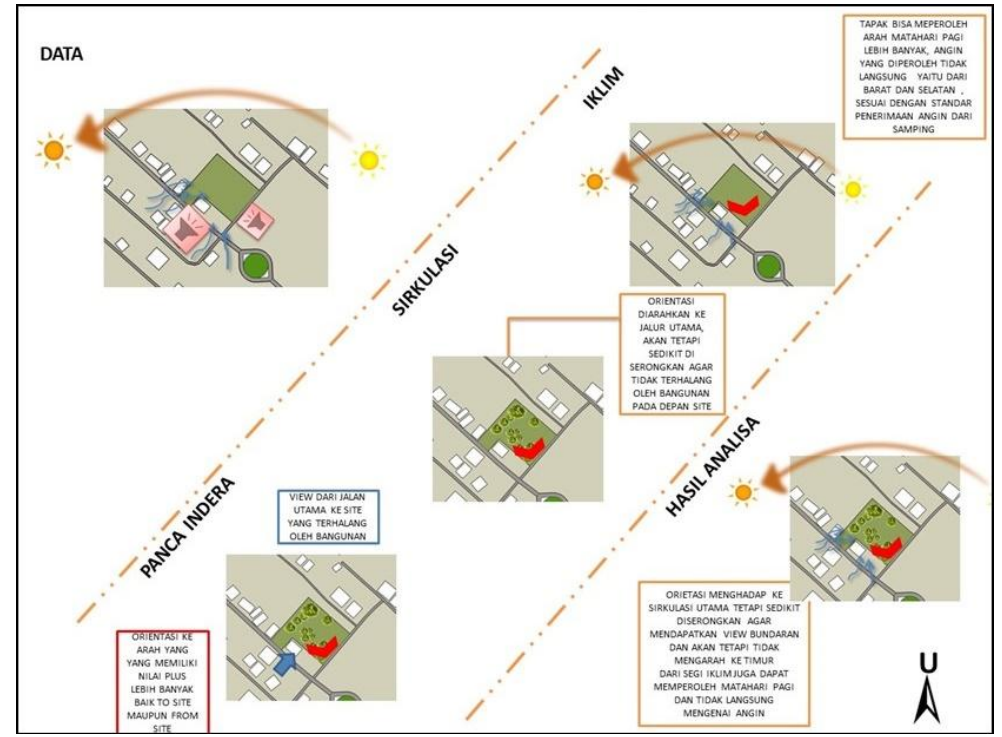

Gambar 4. Analisis Orientasi Pontianak Coffee Shop Sumber: Penulis, 2020

Penggunaan vegetasi pada site menyesuaikan kondisi sekitar site. Zona yang panas dan memerlukan buffer untuk memberikan shading sehingga muncul fungsi penyejuk. Daerah yang kurang memperoleh vegetasi karena berkaitan dengan sirkulasi baik kendaraan maupun pejalan kaki yang membutuhkan shading lebih banyak. Daerah yang memperoleh kebisingan baik dari warga maupun dari kendaraan sehingga vegetasi perlu ditambah, lebih jelas dapat dilihat pada gambar 5.

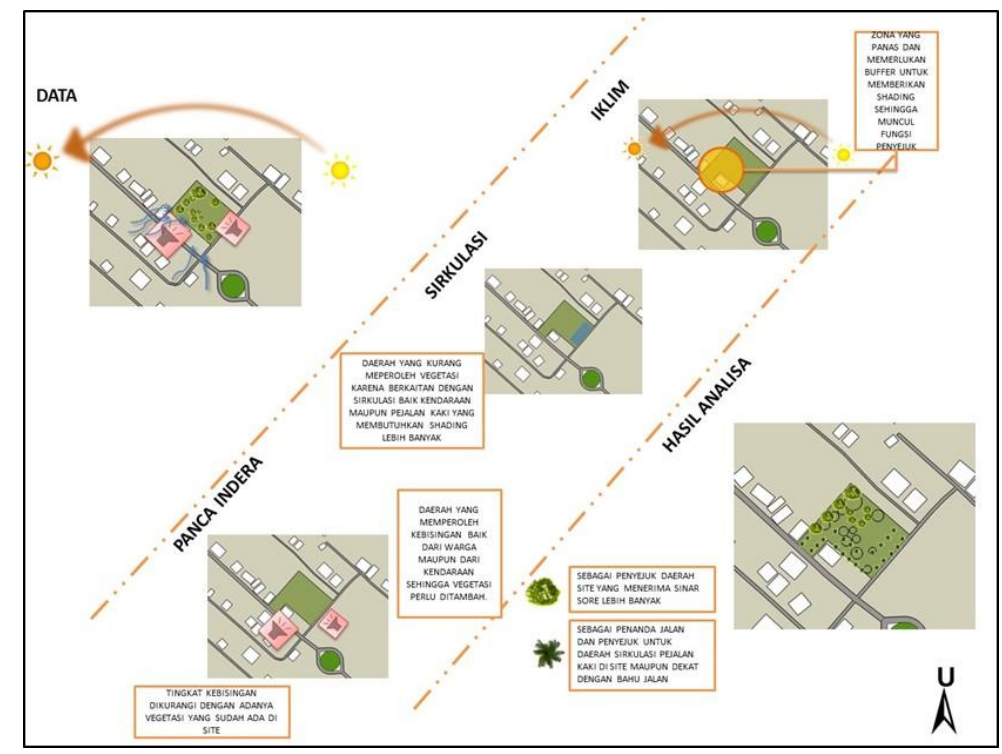

Gambar 5. Analisis Vegetasi Pontianak Coffee Shop

Sumber: Penulis, 2020

Analisis zonasi yang digunakan untuk mengetahui potensi-potensi area dalam lokasi yang dapat digunakan sebagai area publik, servis dan privat. Analisis terhadap sirkulasi dan perletakan, zona servis diletakan dekat dengan sirkulasi alternatif. Zona semi privat diletakan berdekatan dengan zona publik, dan zona semi publik diletakan pada belakang site. Analisis terhadap panca indera, zona servis 
dan publik diletakan dekat dengan akses utamaagar dapat menjadi buffer. Zona semi privat diletakan cukup jauh dari jalan utama agar dapat mencegah kebisingan, lebih jelas dapat dilihat pada gambar 6.

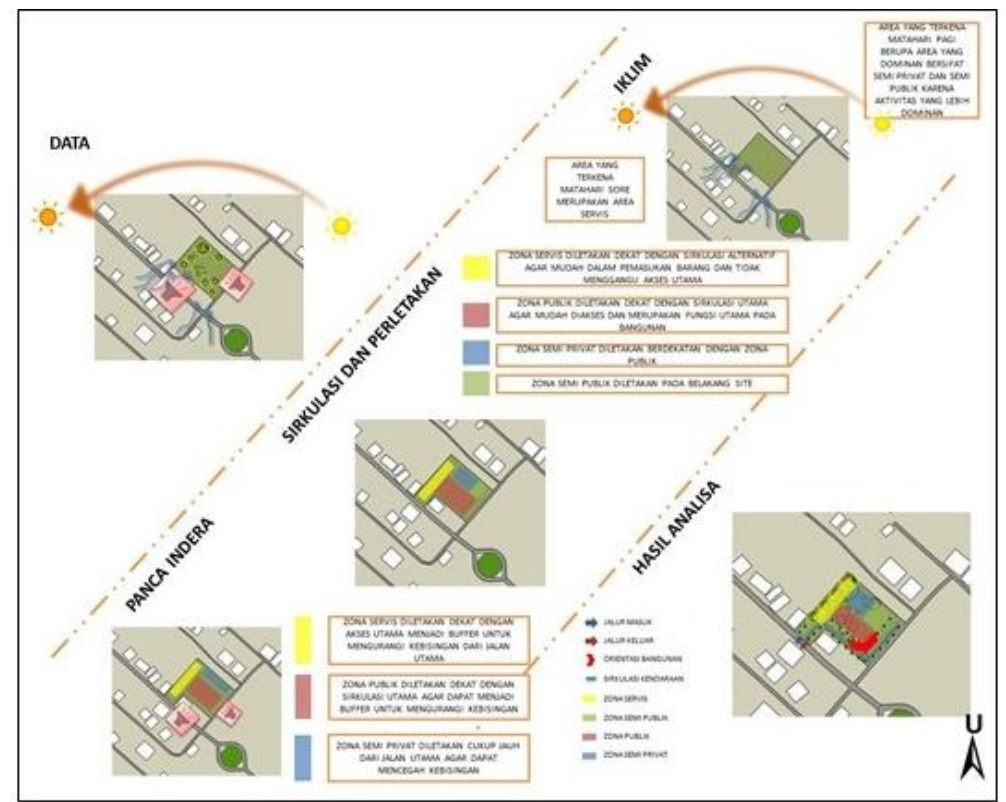

Gambar 6. Analisis Zonasi Pontianak Coffee Shop

Sumber: Penulis, 2020

Besaran ruang diperoleh setelah menentukan kebutuhan ruang berdasarkan jumlah perabot dan sirkulasi. Standar dimensi dan kapasitas yang didapat berdasarkan hitungan yang bersumber dari Neufert (1996), Neufert (2002) dan Analisis. Selain itu juga menggunakan Standar Nasional Perpustakaan (SNP 010: 2011) untuk menetapkan besaran ruang perpustakaan pada coffee shop. Besaran ruang Pontianak Coffee Shop dapat dilihat pada gambar 7.

\begin{tabular}{|c|c|c|c|c|c|c|c|}
\hline No & Nama Ruang & Standar Ruang (M & & Imlh Ruang & Sirkulasi & Luas & Sumber \\
\hline 1 & R. Manager & $13.40 \mathrm{M} 2$ & 1 org & 1 & $30 \%$ & $18 \mathrm{M} 2$ & Nad \\
\hline 2 & R. Supervisor & $13.40 \mathrm{M} 2$ & 1 org & 1 & $30 \%$ & $18 \mathrm{M} 2$ & Nad \\
\hline 3 & R. Karyawan & $15 \mathrm{M} 2$ & 20 org & 1 & $30 \%$ & $19.5 \mathrm{M} 2$ & Anl \\
\hline 4 & R. Pelatihan & $15 \mathrm{M} 2$ & 2 org & 5 & $30 \%$ & $97.5 \mathrm{M} 2$ & Anl \\
\hline 5 & R. Rapat & $2.5 \mathrm{M} 2$ & 12 org & 2 & - & $60 \mathrm{M} 2$ & Nad \\
\hline \multirow{4}{*}{6} & \multirow{4}{*}{ Billiard } & Meja Billiard 7 Feet: 2,73 M2 & \multirow{4}{*}{1 meja } & \multirow{4}{*}{4} & \multirow{4}{*}{ - } & \multirow{4}{*}{$76 \mathrm{M} 2$} & \multirow{4}{*}{ Anl } \\
\hline & & Bench: $1.8 \mathrm{M} 2$ & & & & & \\
\hline & & Rak Stick $0.21 \mathrm{M} 2$ & & & & & \\
\hline & & Total: 4.74 & & & & & \\
\hline 7 & Perpustakaan & $80 \mathrm{M} 2$ & 20 org & 1 & - & $80 \mathrm{M} 2$ & Smpurv \\
\hline 8 & Panggung & $20 \mathrm{Mz}$ & 5 org & 1 & - & $20 \mathrm{M} 2$ & Anl \\
\hline 9 & Co-Working Space & $4 \mathrm{M} 2$ & 20 org & 1 & $30 \%$ & $96 \mathrm{M} 2$ & Anl \\
\hline 10 & Lobby & $54 \mathrm{M} 2$ & 50 org & 1 & - & $54 \mathrm{M} 2$ & Nad \\
\hline 11 & Coffee Store & $129.5 \mathrm{M} 2$ & 50 org & 1 & $30 \%$ & $168.5 \mathrm{M} 2$ & Anl \\
\hline 12 & Smoking Area & Meja + Kursi: 2.125 M2 & 4 org & 10 & $30 \%$ & $29 \mathrm{M} 2$ & Anl \\
\hline 13 & Area Coffee Shop & Meja + Kursi: 2.125 M2 & 4 org & 200 & $30 \%$ & $552.5 \mathrm{M} 2$ & Nad \\
\hline 14 & Area Coffee Shop Terbuka & Meja + Kursi: 2.125 M2 & 4 org & 100 & $30 \%$ & $276.25 \mathrm{Mz}$ & Nad \\
\hline 15 & Taman & Meja + Kursi: 2.125 M2 & 4 org & 50 & $30 \%$ & $140 \mathrm{M} 2$ & Nad \\
\hline 16 & Bar & $15 \mathrm{M} 2$ & 2 org & 4 & $30 \%$ & $78 \mathrm{M} 2$ & Nad \\
\hline 17 & R. Roasting & $2 \mathrm{M} 2$ & 1 org & 1 & $30 \%$ & $2.6 \mathrm{M} 2$ & Anl \\
\hline 18 & Kasir & $4 \mathrm{M} 2$ & 1 org & 1 & $30 \%$ & $5.2 \mathrm{M} 2$ & Nad \\
\hline 19 & Mushola & $24 \mathrm{M} 2$ & 30 org & 2 & - & $48 \mathrm{M} 2$ & Nad \\
\hline \multirow{2}{*}{20} & \multirow{2}{*}{ Parkir } & Motor: 2 M2 & \multirow{2}{*}{$1 \mathrm{mtr} / \mathrm{mbl}$} & Motor: 150 & \multirow{2}{*}{$30 \%$} & Mtr: $520 \mathrm{M} 2$ & \multirow{2}{*}{ Nad } \\
\hline & & Mobil: $12.5 \mathrm{M} 2$ & & Mobil: 20 & & Mы: 487.5 M2 & \\
\hline 21 & Toilet & $2.25 \mathrm{M} 2$ & 1 org & 6 & $=$ & $13.5 \mathrm{M} 2$ & Nad \\
\hline 22 & Janitor & $6 \mathrm{M} 2$ & 2 org & 1 & - & $6 \mathrm{M} 2$ & Nad \\
\hline 23 & Dapur & $15 \mathrm{M} 2$ & 5 org & 1 & $30 \%$ & $97.5 \mathrm{M2}$ & Nad \\
\hline 24 & Gudang & $15 \mathrm{M} 2$ & - & 1 & - & $15 \mathrm{M} 2$ & Nad \\
\hline 25 & Gudang Kopi & $15 \mathrm{M} 2$ & - & 1 & & $15 \mathrm{M} 2$ & Nad \\
\hline 26 & R. Panel & $6 \mathrm{M} 2$ & - & 1 & & $6 \mathrm{M} 2$ & Nad \\
\hline 27 & R. Genset & $9 \mathrm{M} 2$ & - & 1 & & $9 \mathrm{M} 2$ & Nad \\
\hline 28 & R. Pompa & $9 \mathrm{M} 2$ & - & 1 & & $9 \mathrm{M} 2$ & Nad \\
\hline 29 & Pos Security & $6 \mathrm{M2}$ & 1 org & 1 & - & $6 \mathrm{M} 2$ & Nad \\
\hline
\end{tabular}

Gambar 7. Besaran Ruang Pontianak Coffee Shop

Sumber: Penulis, 2020 
Pontianak Coffee Shop terdiri dari 2 (dua) lantai. Pada lantai 1 (satu), terdapat area coffee shop, area komersil, area bar dan area servis. Sedangkan pada lantai 2 (dua) terdapat area coffee shop, area bar, area rekreasi, area edukasi dan kantor pengelola. Organisasi ruang menggambarkan hubungan antar ruang sehingga terlihat kedekatan ruang dan susunan letak ruang sebelum disusun menjadi denah, lebih jelas dapat dilihat pada gambar 8.

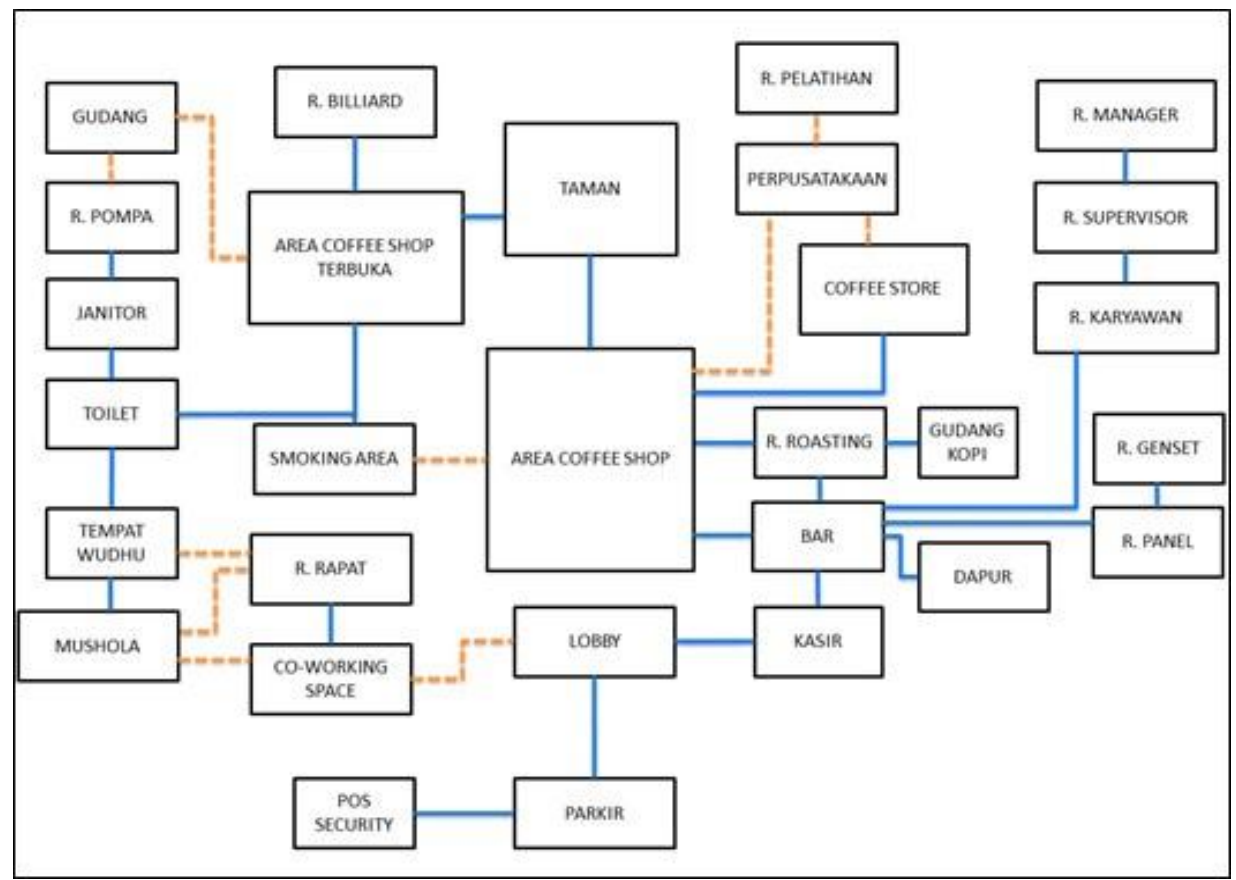

Gambar 8. Organisasi Ruang Pontianak Coffee Shop

Sumber: Penulis, 2020

Konsep gubahan bentuk dari bangunan Pontianak Coffee Shop mengambil bentukan dasar mengikuti site agar dapat memaksimalkan luasan site yang ada. Mengalami pengurangan bentuk pada sisi depan yang berorientasi kejalan utama dan view yang baik. pengurangan bentuk pada sisi belakang agar setiap sisi mendapatkan cahaya matahari pada pagi hari dan penambahan bentuk pada sisi depan agar lebih menonjol daripada sisi lain dan menjadikan ruang utama, dapat dilihat pada gambar 9.

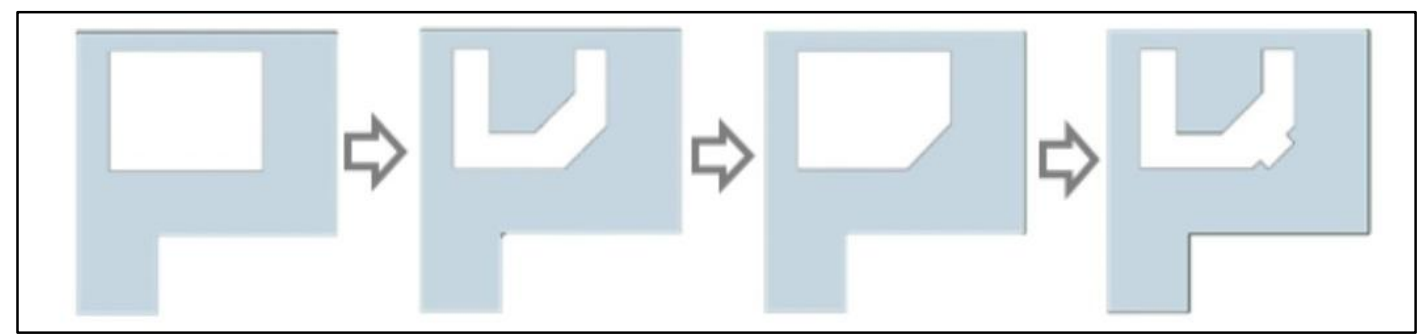

Gambar 9. Gubahan Bentuk Pontianak Coffee Shop

Sumber: Penulis, 2020

Tata ruang dalam merupakan susunan ruang atau gambaran denah kasar setelah ditentukan hubungan ruang dan organisasi ruang. Tata ruang dalam lantai 1 (satu) sebagian besar merupakan zona publik. Zona publik pada Pontianak Coffee Shop antara lain adalah lobby, taman, ruang roasting dan area coffee shop. Selain zona publik, pada lantai 1 (satu) juga terdapat area semi publik, antara lain yaitu area bar, co-working space dan area komersil. Terdapat zona servis yaitu toilet, janitor, ruang pompa, gudang, tempat wudhu dan mushola, lebih jelas dapat dilihat pada gambar $\mathbf{1 0 .}$ 


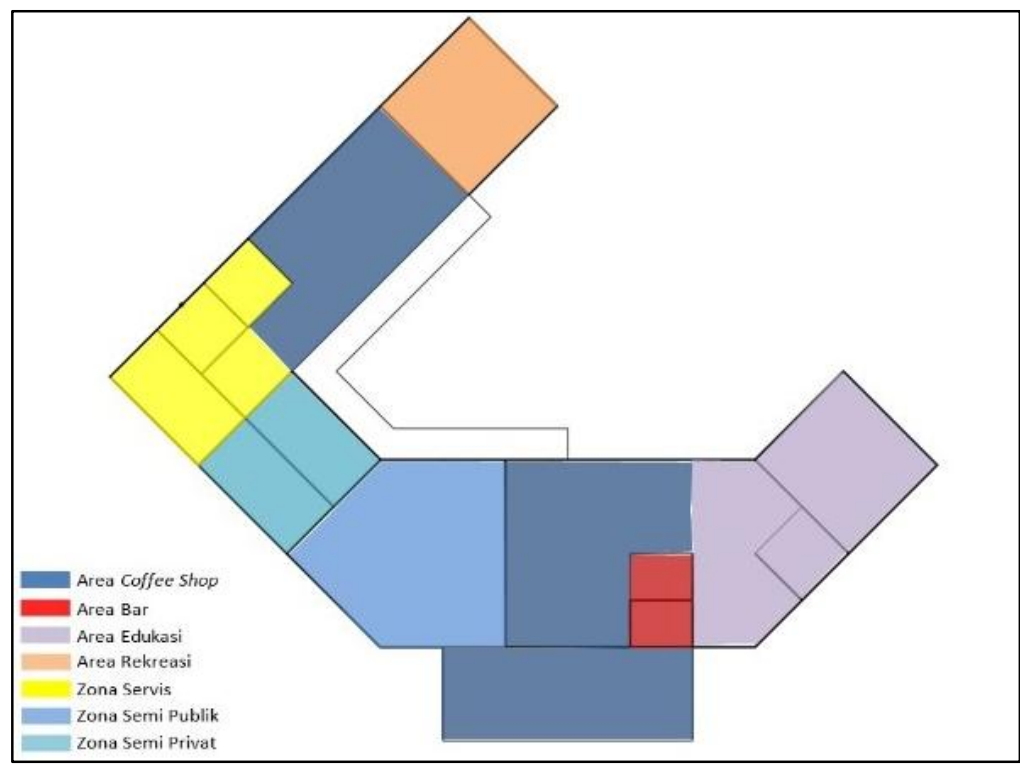

Gambar 10. Tata Ruang Dalam lantai 1 Pontianak Coffee Shop Sumber: Penulis, 2020

Tata ruang dalam lantai 2 (dua) terdiri dari zona publik, antara lain adalah area coffee shop. Selain itu juga terdapat zona semi publik, antara lain yaitu area bar, area edukasi berupa perpustakan dan area rekreasi berupa tempat bermain Billiard. Terdapat zona semi privat seperti ruang rapat, ruang karyawan dan ruang pelatihan serta zona privat seperti ruang manager dan ruang supervisor, dapat dilihat pada gambar 11.

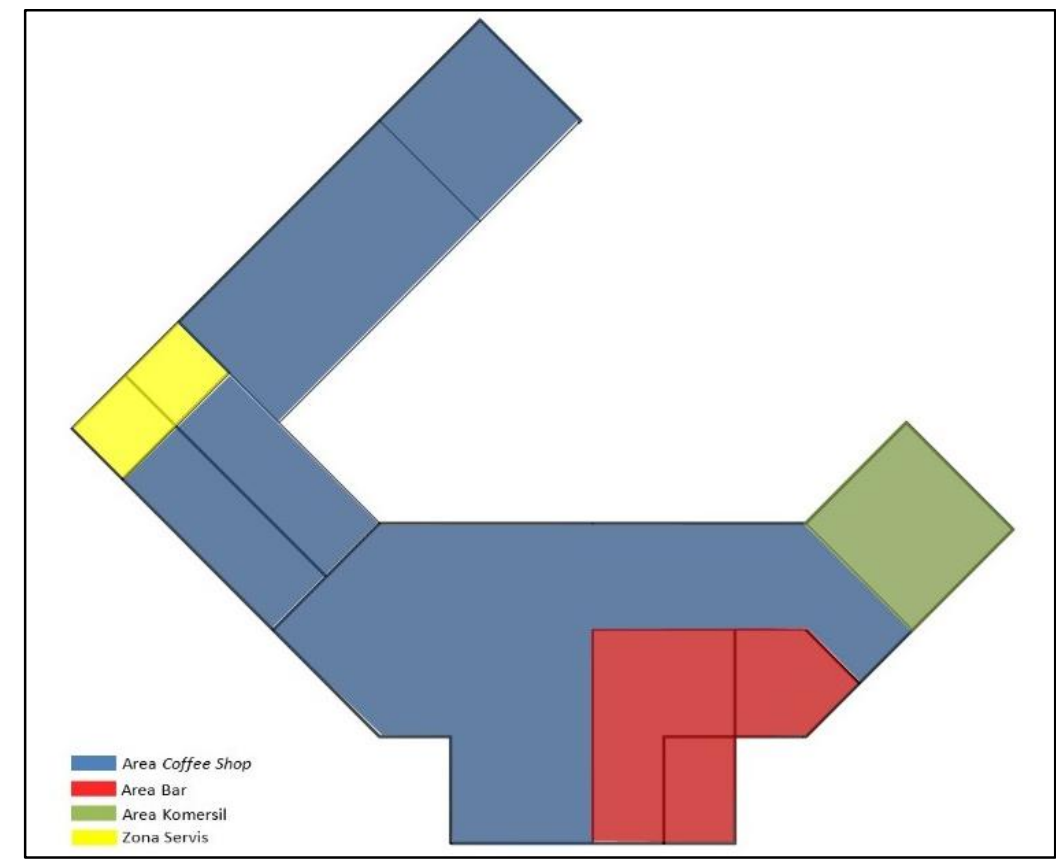

Gambar 11. Tata Ruang Dalam lantai 2 Pontianak Coffee Shop Sumber: Penulis, 2020

Konsep tata ruang luar menggambarkan bagaimana perletakan bangunan terhadap lingkungan diluar bangunan serta menjelaskan fungsi area diluar bangunan. Tata ruang luar Pontianak Coffee Shop terdiri dari zona semi publik yaitu berupa taman dan outdoor coffee shop, serta zona servis yaitu area parkir. Tata ruang luar Pontianak Coffee Shop dapat dilihat pada gambar 12. 


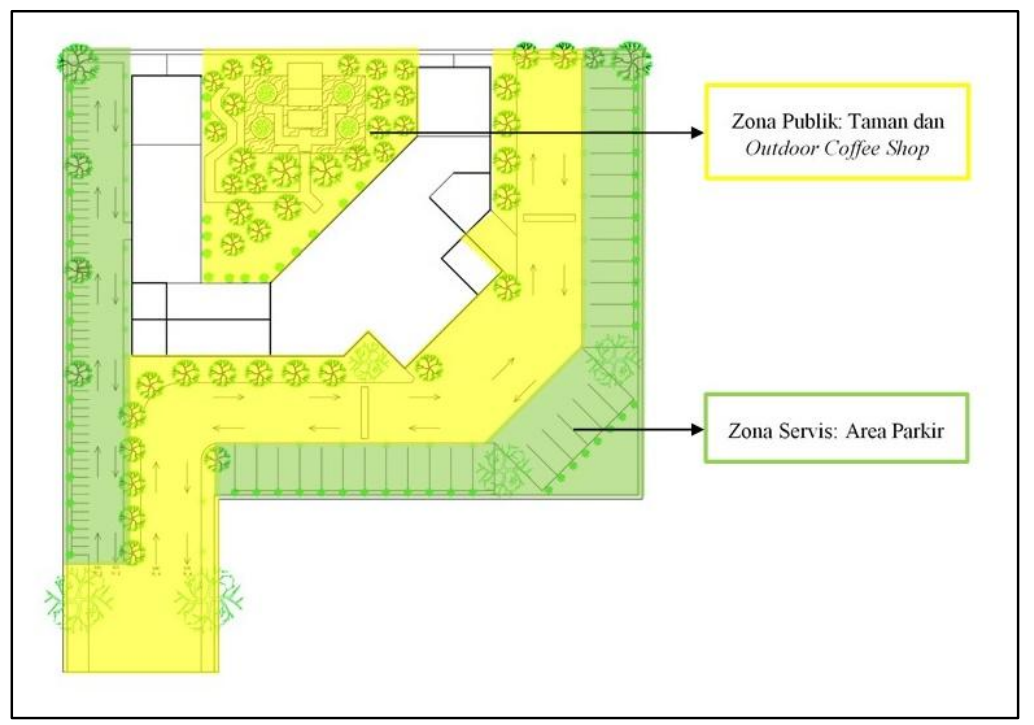

Gambar 12. Tata Ruang Luar Pontianak Coffee Shop Sumber: Penulis, 2020

Bangunan Pontianak Coffee Shop menggunakan struktur rangka. Material rangka yang digunakan adalah rangka beton bertulang. Pondasi yang digunakan adalah pondasi Mini Pile karena menyesuaikan jenis tanah di Pontianak. Kolom dan balok yang digunakan pada bangunan ialah beton bertulang. Pada dinding bangunan digunakan material batako karena proses pengerjaan konstruksi cepat dan hemat biaya. Atap yang digunakan adalah atap pelana, karena lokasi perancangan memiliki curah hujan yang cukup tinggi dan atap dak beton karena memiliki daya tahan yang kuat, dapat menghalau panas, tidak mudah terbakar dan mudah dalam pengerjaan.

Distribusi air bersih menggunakan sistem up feed. Distribusi air bersih diarahkan dengan tekanan pompa ke unit sanitasi yang terdiri dari mesin pompa, tangki air bersih bawah tanah. Limbah dari bangunan Pontianak Coffee Shop tidak memerlukan pengolahan khusus karena limbah yang dihasilkan berupa sisa dari olahan biji kopi yang merupakan limbah yang mudah terurai. Limbah tetap akan ditampung di tempat penampungan ataupun bak kontrol terlebih dahulu. Sistem pembuangan kotoran dibuang ke tempat penampungan yaitu septictank. Sedangkan air kotor langsung dibuang ke sumur resapan yang selanjutnya dialirkan ke riol kota.

Tata udara yang digunakan ialah kipas angin dan AC Split karena ruang pada Pontianak Coffee Shop berukuran kecil seperti ruang pelatihan, ruang karyawan, ruang manager dan ruang supervisor. Area dapur menggunakan exhaust fan untuk mengeluarkan udara panas agar suhu ruangan tetap stabil. Keamanan kebakaran menggunakan detector asap, sprinkler, APAP, dan hidran.

\section{Hasil}

Sirkulasi utama kawasan merupakan jalur sirkulasi utama keluar masuk pada coffee shop. Tata letak pada sirkulasi harus mempertimbangkan akses masuk, keamanan, kenyamanan dan kemudahan, analisa tapak dan lingkungan coffee shop. Sirkulasi pada Pontianak coffee shop direncanakan menyesuaikan dengan akses sirkulasi utama pada lokasi perancangan. Pintu masuk dan keluar untuk kendaraan roda 4 dan 2 berada di sisi depan kiri site. Area parkir kendaraan diletakkan pada depan dan samping bangunan agar mudah diakses oleh pengunjung. Pengunjung yang menggunakan kendaraan akan masuk ke site kemudian diarahkan untuk drop off pada area depan bangunan. Terdapat akses menuju area parkir yang terletak di depan dan sisi samping kiri pada site. Sirkulasi internal (karyawan/staff) melalui pintu masuk yang berbeda dengan sirkulasi eksternal dan langsung menuju area parkir kendaraan. Pintu keluar sirkulasi internal juga berbeda dengan jalur utama untuk pengunjung, suasana kawasan Pontianak Coffee Shop dapat dilihat pada gambar 13. 


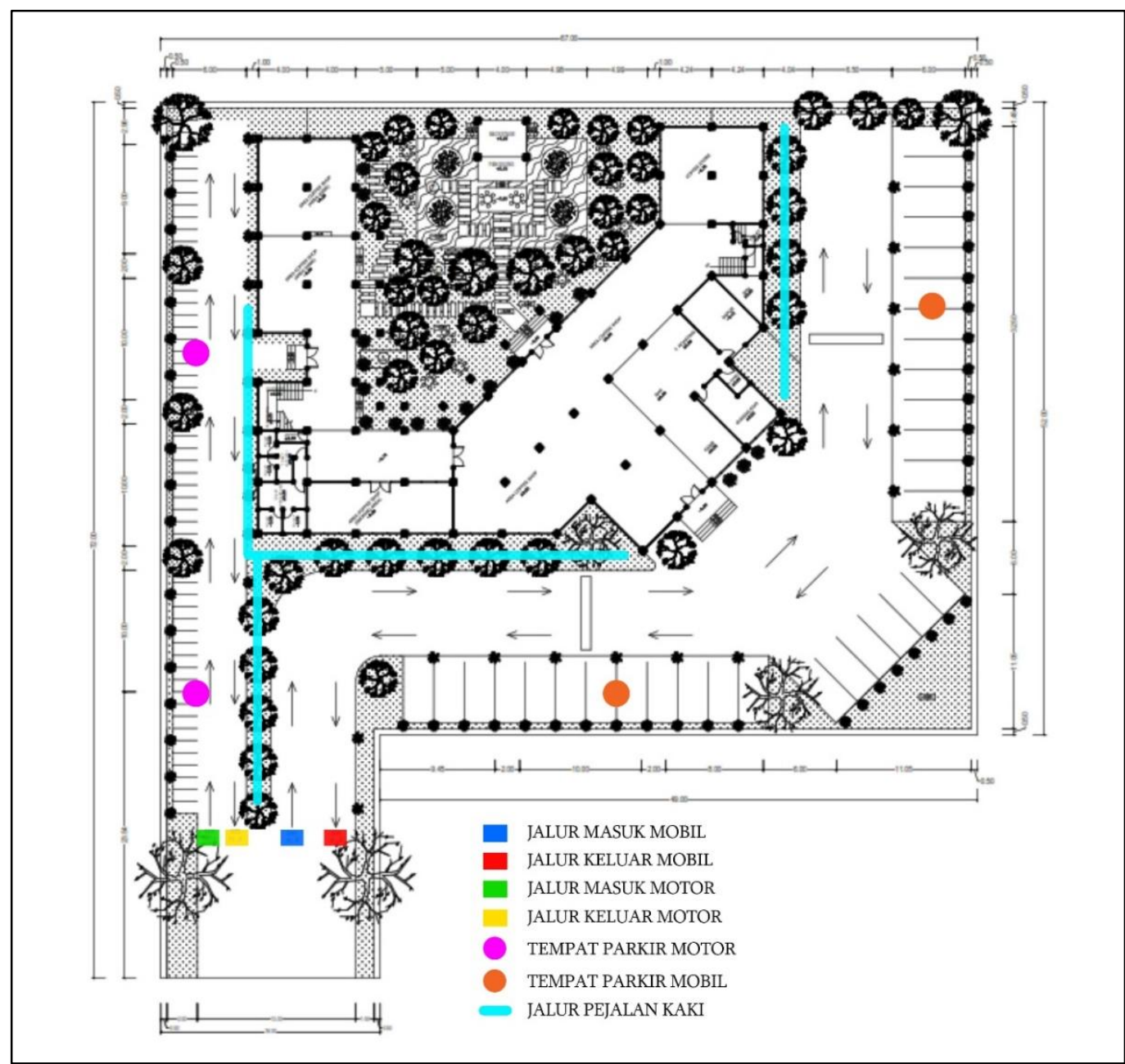

Gambar 13. Siteplan Pontianak Coffee Shop

Sumber: Penulis, 2020

Gambar denah lantai 1 (satu) menggambarkaan susunan ruang yang terdiri dari zona publik (bar, area coffee shop indoor, coffee store, area coffee shop, smoking area, area game), zona servis (gudang, gudang kopi, ruang panel, ruang pompa, ruang AHU, dapur, toilet, dan janitor). Denah lantai 2 (dua) menggambarkan susunan ruang yang terdiri dari zona publik (bar, area coffee shop), zona semi publik (ruang billiard, perpustakaan, co-working space), zona privat (ruang pengelola), zona semi privat (ruang pelatihan, ruang rapat), zona servis (mushola, tempat wudhu, toilet), lebih jelas dapat dilihat pada gambar 14 dan gambar 15. 


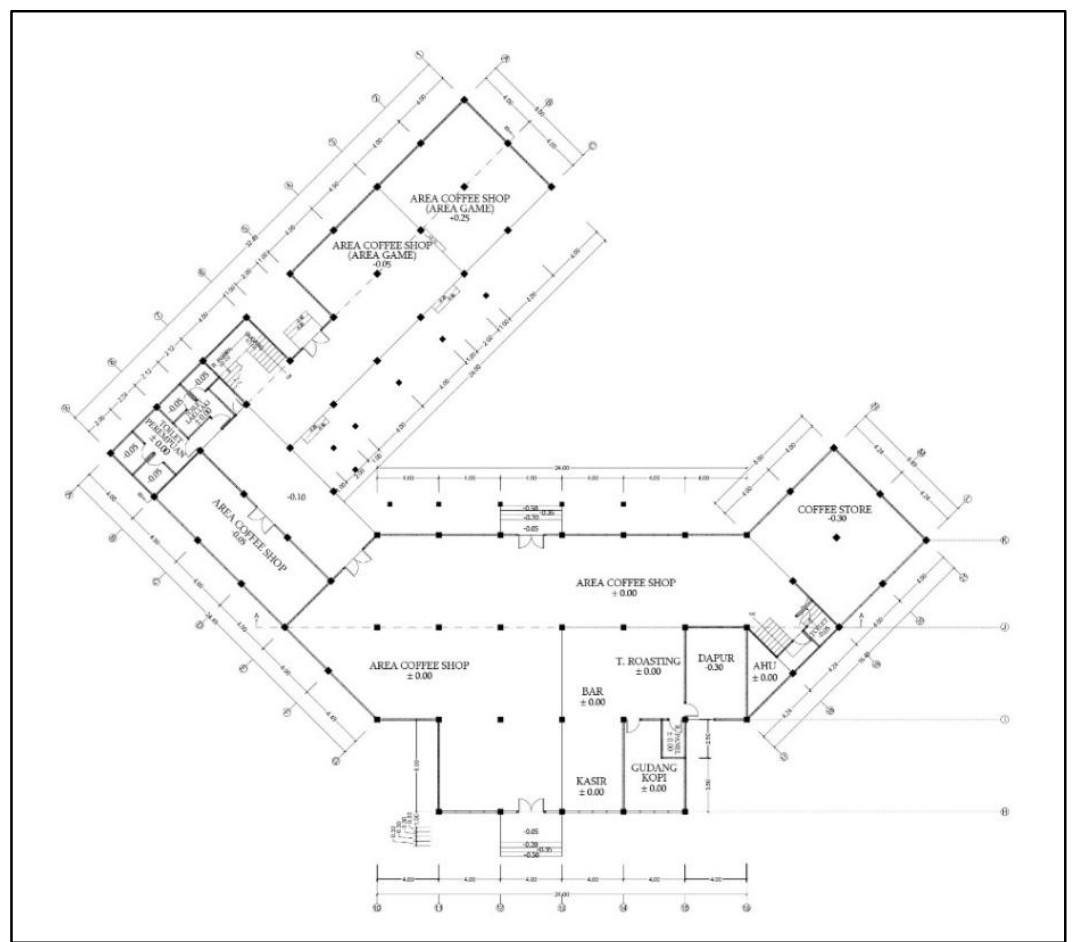

Gambar 14. Denah lantai 1 Pontianak Coffee Shop

Sumber: Penulis, 2020

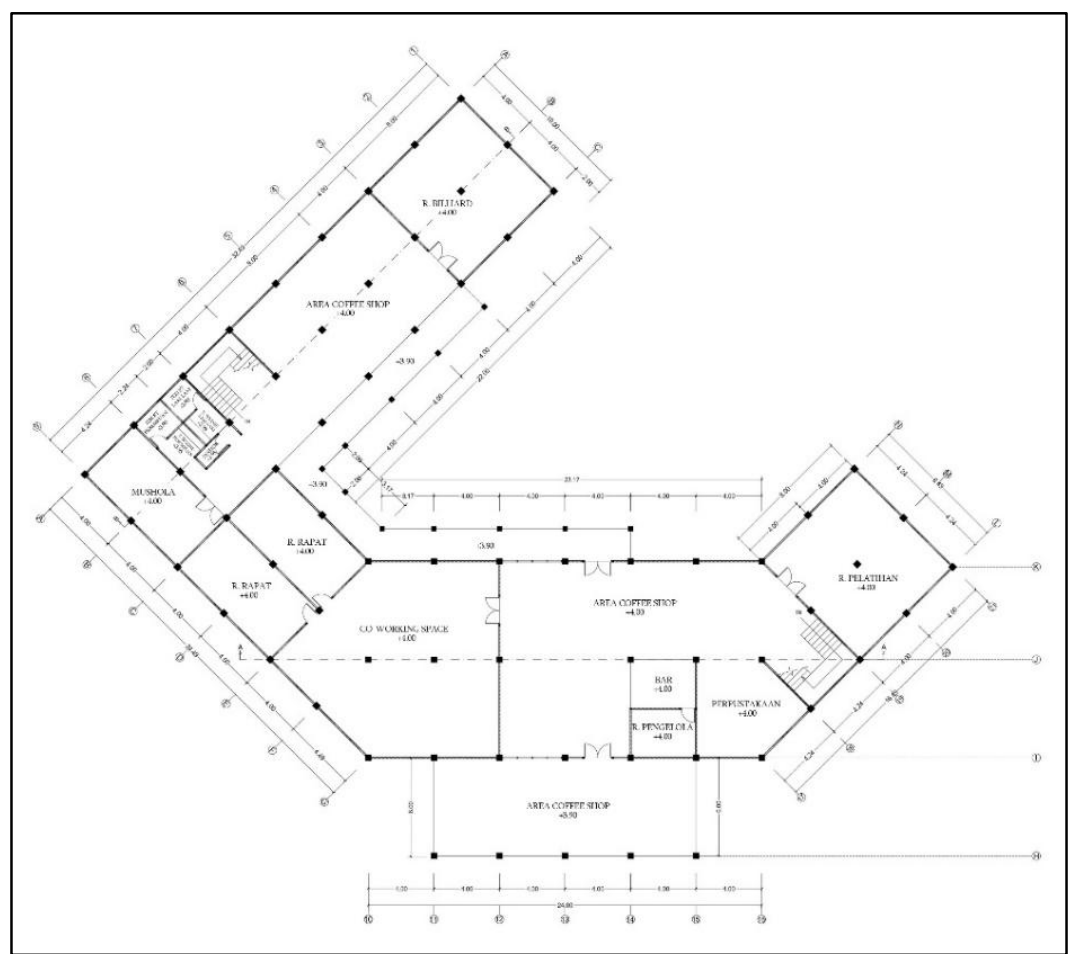

Gambar 15. Denah lantai 2 Pontianak Coffee Shop

Sumber: Penulis, 2020

Konsep pada bangunan mengambil bentukan dasar pada site, kemudian mengalami penambahan dan pengurangan bentuk. Atap bangunan menggunakan atap pelana dikarenakan curah hujan yang cukup tinggi. Pada sisi depan, atap pelana dominan lebih lebar dan tinggi agar menjadi pusat dari 
bangunan Pontianak Coffee Shop. Dinding depan bangunan menggunakan gabungan ornamen dari Tionghoa, Dayak, dan Melayu.

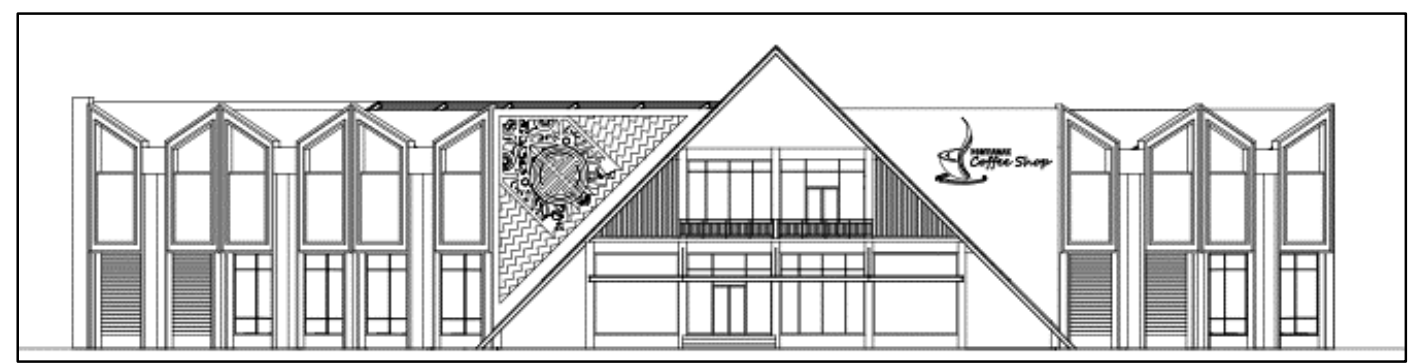

Gambar 16. Tampak Depan Pontianak Coffee Shop Sumber: Penulis, 2020

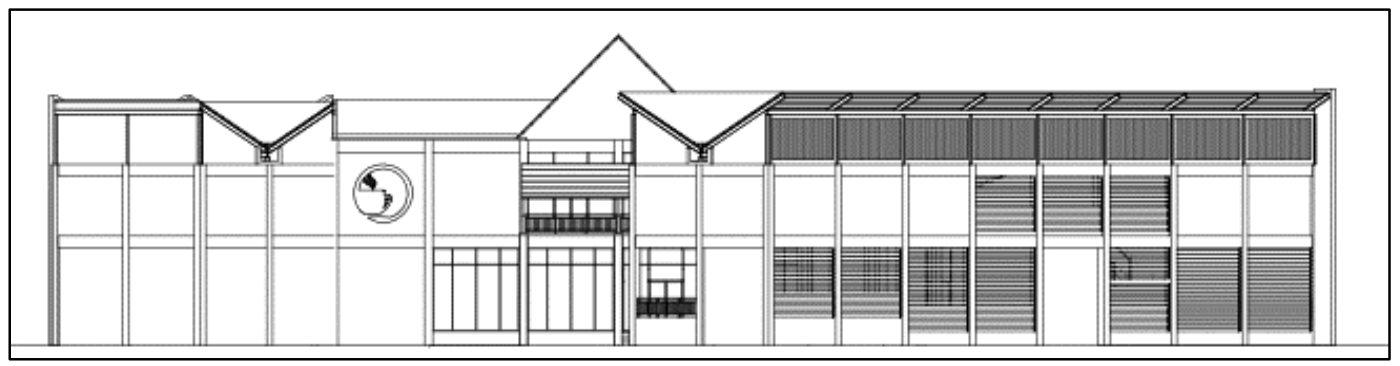

Gambar 17. Tampak Belakang Pontianak Coffee Shop Sumber: Penulis, 2020

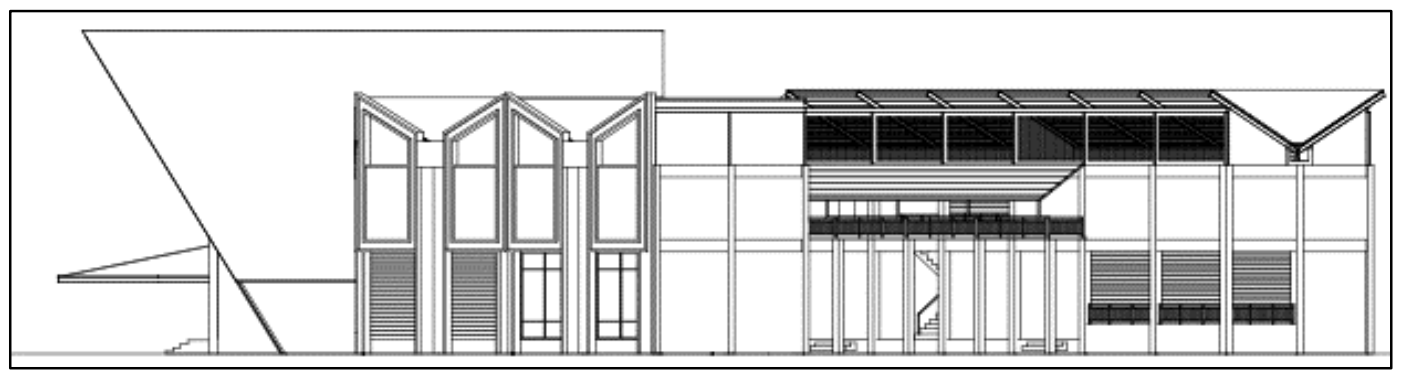

Gambar 18. Tampak Samping Kanan Pontianak Coffee Shop

Sumber: Penulis, 2020

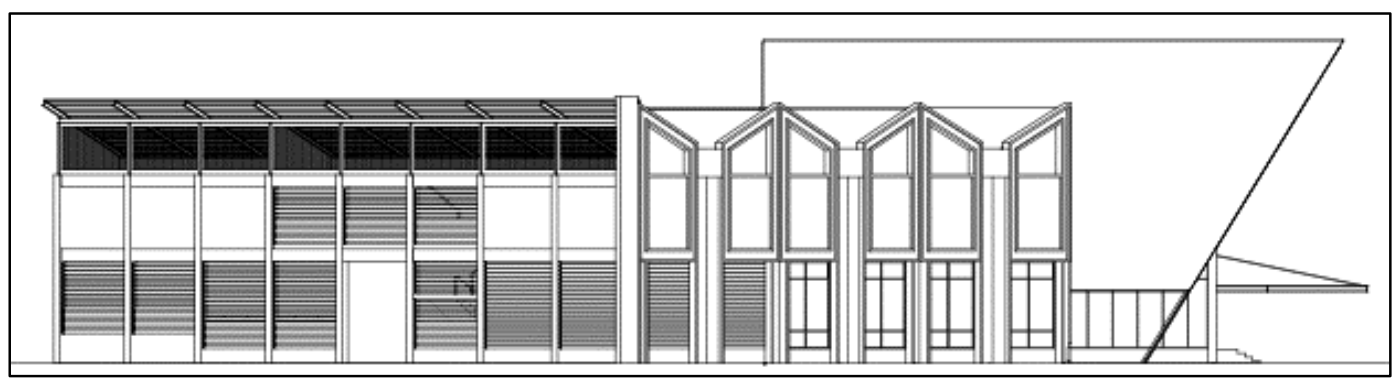

Gambar 19. Tampak Samping Kiri Pontianak Coffee Shop

Sumber: Penulis, 2020

Gambar potongan memperlihatkan sirkulasi pada bangunan yang berupa tangga pada area samping kanan dan kiri bangunan yang berfungsi untuk mempermudah konsumen mengakses lantai satu dan lantai 2 pada bangunan Pontianak Coffee Shop, lebih jelas dapat dilihat pada gambar 20 dan gambar 21. 


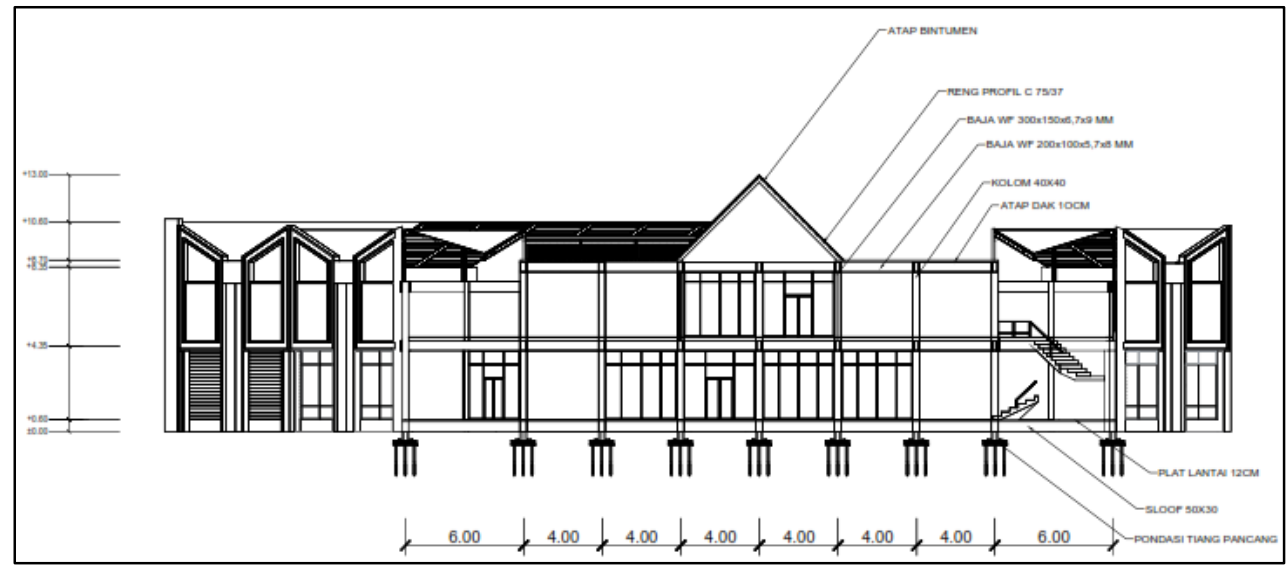

Gambar 20. Potongan A-A Pontianak Coffee Shop Sumber: Penulis, 2020

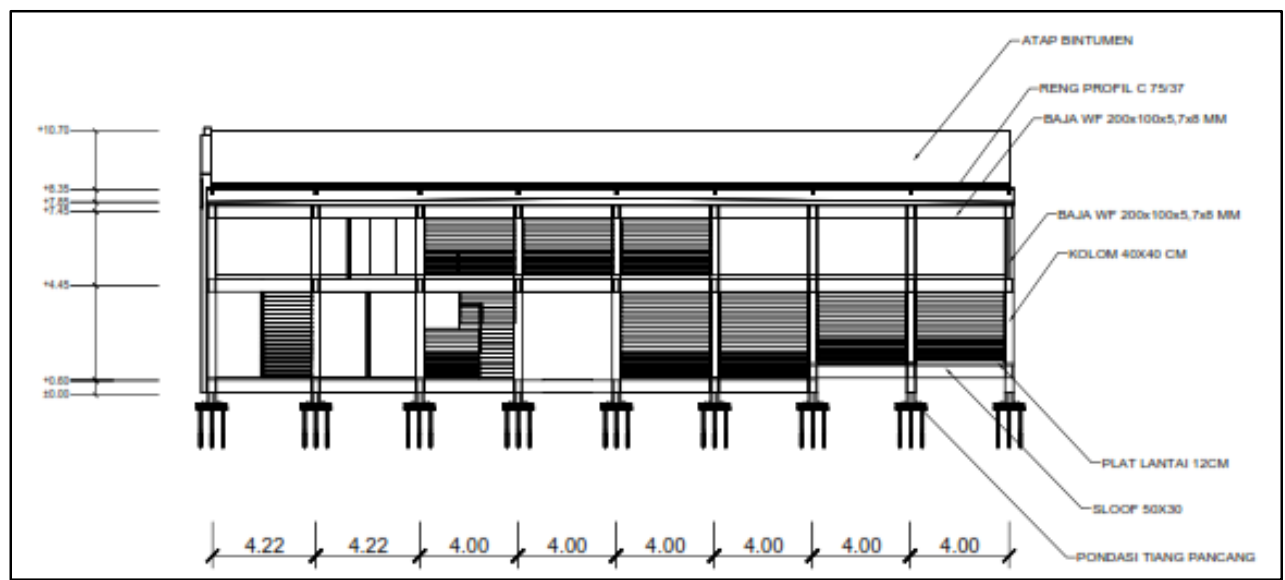

Gambar 21. Potongan B-B Pontianak Coffee Shop

Sumber: Penulis, 2020

Konsep yang diterapkan pada interior area coffee shop ialah natural. Finishing material yang digunakan pada dinding dan lantai yaitu semen ekspos, sedangkan untuk plafon menggunakan material kayu agar terkesan natural. Plafon pada bangunan di desain melengkung dan diberi lampu LED agar terkesan megah, lebih jelas dapat dilihat pada gambar 22 dan gambar 23.

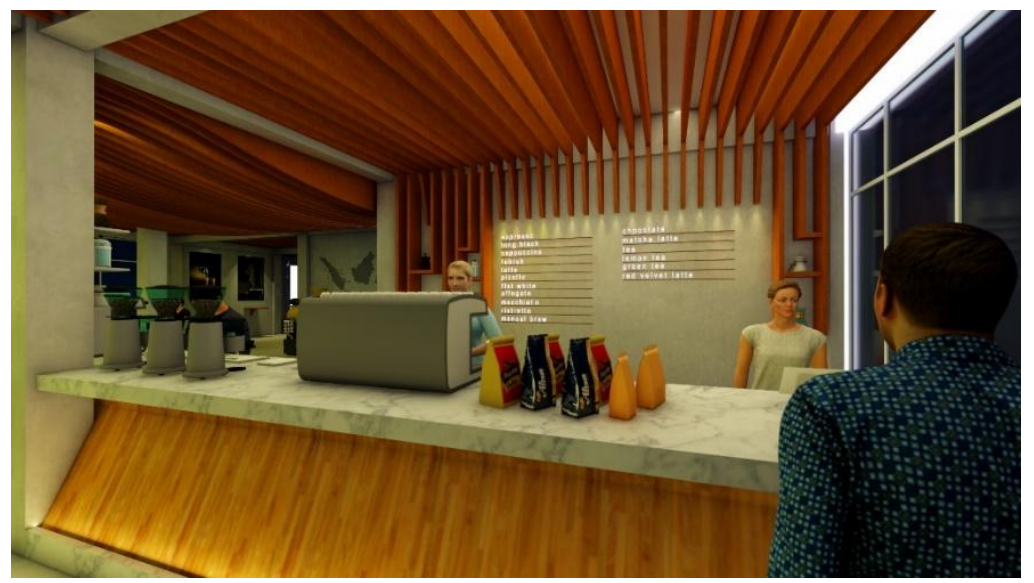

Gambar 22. Suasana Ruang Dalam 1 Pontianak Coffee Shop

Sumber: Penulis, 2020 


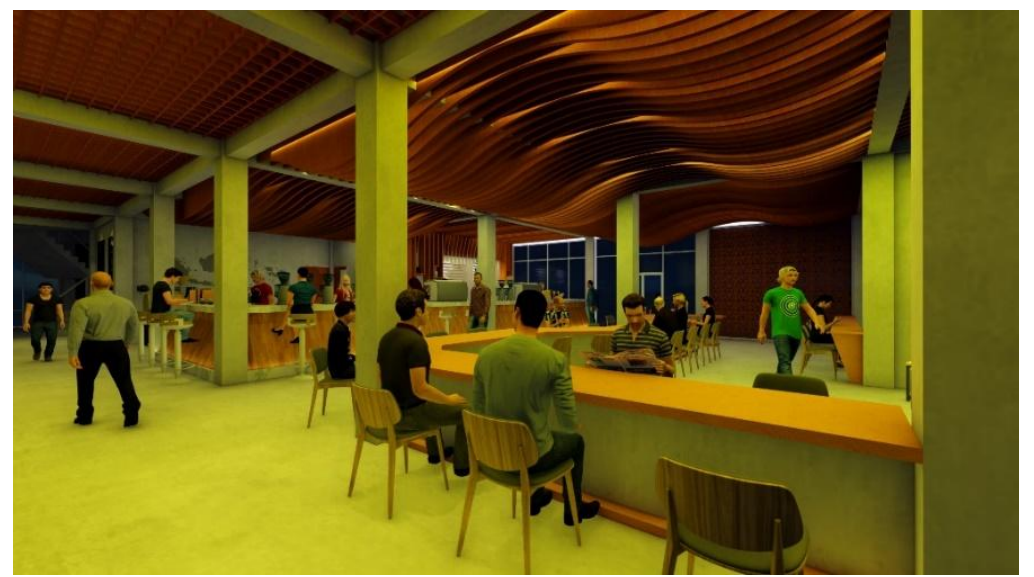

Gambar 23. Suasana Ruang Dalam 2 Pontianak Coffee Shop Sumber: Penulis, 2020

Pada sisi depan bangunan dirancang dengan menggunakan atap pelana karena curah hujan yang cukup tinggi dan menggunakan material-material yang terkesan natural seperti semen ekspos, kayu, dan bata merah. Sisi belakang bangunan terdapat taman yang berfungsi sebagai tempat untuk menikmati kopi dan bersantai, area ini juga terdapat kolam dan panggung musik, dapat dilihat pada gambar 24 dan gambar 25.

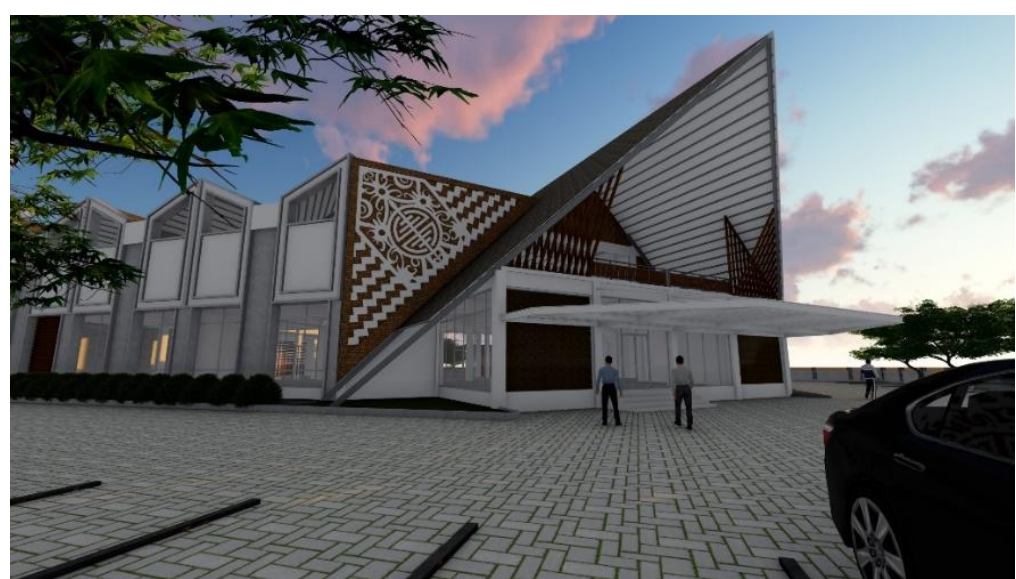

Gambar 24. Suasana Ruang Luar 1 Pontianak Coffee Shop Sumber: Penulis, 2020

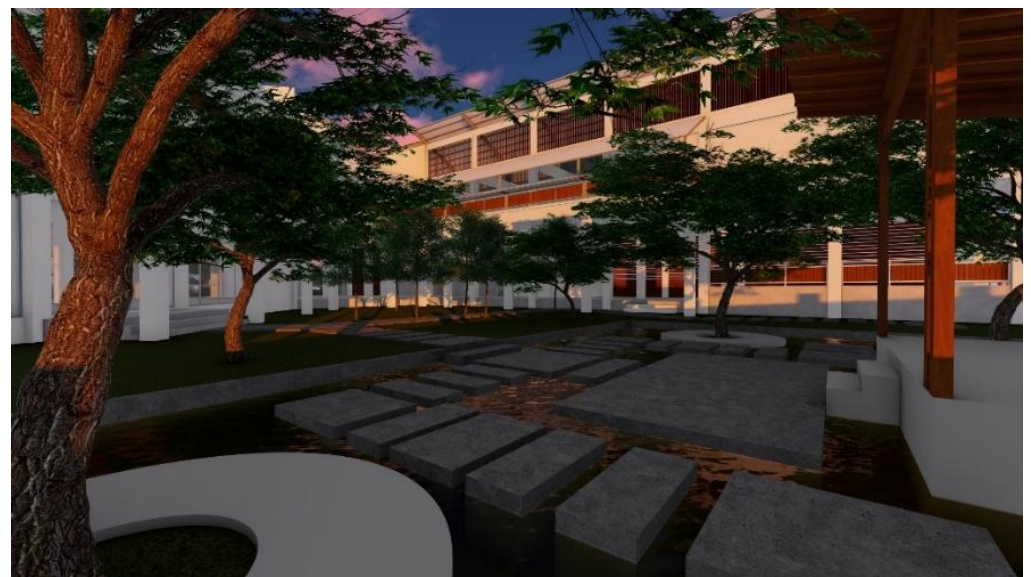

Gambar 25. Suasana Ruang Luar 2 Pontianak Coffee Shop

Sumber: Penulis, 2020 


\section{Kesimpulan}

Dalam perancangan pada Pontianak Coffee Shop, Perkembangan konsumsi kopi di Kota Pontianak telah menyebabkan peningkatan jumlah coffee shop. Akan tetapi, coffee shop yang terdapat di Kota Pontianak masih sangat minim yang memiliki tempat penyangraian, tempat penjualan alat dan produk kopi, serta belum adanya wadah edukasi. Maka dari itu, perancangan Pontianak coffee shop menyediakan fasilitas penunjang berupa pengolahan, edukasi, dan penjualan. Konsep pada bangunan Pontianak Coffee Shop mengadopsi bentuk bangunan tropis, dan memberikan sentuhan alam pada interior dan eksterior bangunan. Pontianak Coffee Shop dominan menggunakan material lokal.

\section{Ucapan Terima Kasih}

Ucapan syukur kepada Tuhan Yang Maha Esa, kepada orang tua penulis, kepada dosen pembimbing Proyek Tugas Akhir yaitu Ibu Emilya Kalsum, S.T., M.T selaku Dosen Pembimbing I dan Ibu Lestari S.T., M.T selaku Dosen Pembimbing II yang telah banyak memberikan pengarahan, pengetahuan dalam menyelesaikan penyusunan Tugas Akhir. Kepada seluruh dosen dan staf prodi arsitektur serta teman-teman, dan seluruh pihak yang telah banyak memberikan doa dan dukungan dalam pengerjaan Proyek Tugas Akhir ini.

\section{Daftar Acuan}

Barus, H. (2011, September 21). Kawasan Gajah Mada Pontianak Dicanangkan Coffee Street. Retrieved from https://investor.id

Boston, A. (2020, September 16). Struktur Organisasi Restoran dan Tugasnya. Retrieved from https://www.amesbostonhotel.com

Distan. (2019, March 29). Sejarah Perkembangan Kopi. Retrieved from https://distan.bulelengkab.go.id

Neufert, E. (1996). Data Arsitek Jilid 1. Jakarta: Erlangga

Neufert, E. (2002). Data Arsitek Jilid 2. Jakarta: Erlangga

Pemerintah Daerah Kota Pontianak. (2013). Peraturan Daerah Kota Pontianak tentang Rencana Tata Ruang Wilayah Kota Pontianak Tahun 2013 -2033. Pontianak: Pemerintah Daerah Kota Pontianak

Perpustakaan Nasional. (2011, November 12). SNP 010:2011 tentang Standar Nasional Perpustakaan. Retrieved from https://www.pustakawanmendunia.org

Prayudi, D. (2015, May 24). Cerita di Balik Secangkir Kopi Pontianak. Retrieved from https://www.tukangjalanjajan.com

Sugiarto, E. \& Sulartiningrum, S. (1996). Pengantar Industri Akomodasi dan Restoran. Jakarta: PT. Gramedia Pustaka Utama

Yazid. (1999). Pemasaran Jasa Konsep dan Implementasi. Yogyakarta: Ekonisia 